\title{
Cytotoxicity Testing of Temporary Luting Cements with Two- and Three-Dimensional Cultures of Bovine Dental Pulp-Derived Cells
}

\author{
Hayriye Esra Ülker, ${ }^{1}$ Mustafa Ülker, ${ }^{1}$ Hasan Önder Gümüş, ${ }^{2}$ \\ Muhammet Yalçın, ${ }^{3}$ and Abdulkadir Şengün ${ }^{4}$ \\ ${ }^{1}$ Department of Restorative Dentistry, Faculty of Dentistry, Selcuk University, 42075 Konya, Turkey \\ ${ }^{2}$ Department of Prosthodontics, Faculty of Dentistry, Erciyes University, 38039 Kayseri, Turkey \\ ${ }^{3}$ Department of Restorative Dentistry, Faculty of Dentistry, Inonu University, 44280 Malatya, Turkey \\ ${ }^{4}$ Department of Restorative Dentistry, Faculty of Dentistry, Kırıkkale University, 71100 Kırıkale, Turkey
}

Correspondence should be addressed to Hayriye Esra Ülker; botsalie@hotmail.com

Received 19 April 2013; Accepted 8 July 2013

Academic Editor: Andre Van Wijnen

Copyright (C) 2013 Hayriye Esra Ülker et al. This is an open access article distributed under the Creative Commons Attribution License, which permits unrestricted use, distribution, and reproduction in any medium, provided the original work is properly cited.

\begin{abstract}
This study evaluated the cytotoxicity of eugenol-containing and eugenol-free temporary luting cements. For cytotoxicity testing, bovine pulp-derived cells transfected with Simian virus 40 Large $\mathrm{T}$ antigen were exposed to extracts of eugenol-containing (Rely $\mathrm{X}$ Temp E) and eugenol-free (Provicol, PreVISION CEM, and Rely X Temp NE) temporary luting cements for 24 h. The cytotoxicity of the same materials was also evaluated in a dentin barrier test device using three-dimensional cell cultures of bovine pulp-derived cells. The results of the cytotoxicity studies with two-dimensional cultures of bovine dental pulp-derived cells revealed that cell survival with the extracts of Rely X Temp E, Provicol, PreVISION CEM, and Rely X Temp NE was 89.1\%, 84.9\%, 92.3\%, and 66.8\%, respectively. Rely X Temp NE and Provicol showed cytotoxic effects on bovine dental pulp-derived cells $(P<0.05)$. The results of the dentin barrier test revealed that cell survival with the above-mentioned temporary cement was $101.5 \%, 91.9 \%, 93.5 \%$, and $90.6 \%$, respectively. None of the temporary luting cements significantly reduced cell survival compared with the negative control in the dentin barrier test $(P>0.05)$. Biologically active materials released from temporary luting cements may not influence the dentine-pulp complex if the residual dentine layer is at least $0.5 \mathrm{~mm}$ thick.
\end{abstract}

\section{Introduction}

Indirect restorations generally require less chair side time and provide better proximal contacts, esthetics, tooth morphology, and marginal accuracy than direct restorations $[1,2]$. However, as indirect procedures require multiple appointments, the use of temporary restorations and temporary luting cements is necessary to cover the prepared part of the tooth and to protect the pulp from external stimuli, before a patient's cosmetic and functional needs are fully restored [2, 3]. Sometimes temporary restorations may have to function for an extended period of time as a result of unforeseen events such as laboratory delays or patient unavailability $[4,5]$. Moreover, the provisional cementation of permanent restorations by temporary luting cements is widely practiced for a variety of clinical reasons, including the desire to make further functional, occlusal, and esthetic adjustments $[5,6]$.

Therefore, provisional or definitive restorations may be placed with temporary luting cement for an extended time period. During this period, the abutments need the best possible biological and mechanical protection. This ensures that the vitality of the pulp and the integrity of mineralized tissues are preserved. As temporary luting cements come into close and relatively prolonged contact with the vital dentin-pulp complex, their influence on pulp tissue is very important. Thus, the biocompatibility of temporary luting cements is a relevant aspect of these materials clinical success. The biological safety of permanent conventional and 
adhesive dental luting cements has been studied extensively, and prior findings demonstrate varying degrees of biological effects [7-12]. However reports on the biological safety of temporary luting cements are still very rare. In a recent in vivo study, Bagis et al. demonstrated that temporary luting cements altered the expression of endothelial cell adhesion molecules in the dental pulp [13].

To evaluate the cytotoxicity of temporary luting cements on bovine dental pulp-derived cells completely, this study first included an evaluation of cytotoxicity of several temporary luting cements (RelyX Temp E, Provicol, PreVISION CEM, and RelyX Temp NE) on two-dimensional monolayer cultures of bovine dental pulp-derived cells. In addition, the cytotoxicity of temporary luting cements was also evaluated in a dentin barrier test device using three-dimensional cultures of bovine dental pulp-derived cells to mimic an in vivo situation. The null hypothesis of this study was that temporary luting cements are not cytotoxic to both twodimensional monolayer cultures and the three-dimensional cultures of bovine dental pulp-derived cells.

\section{Materials and Methods}

2.1. Preparation of Extracts and Cytotoxicity Testing Using Bovine Dental Pulp-Derived Cells. Three eugenol-free temporary luting cements were tested: Provicol (Voco $\mathrm{GmbH}$, Cuxhaven, Germany), PreVISION CEM (Heraeus Kulzer GmbH \& Co. KG, Hanau, Germany), and RelyX Temp NE (3 M ESPE, Seefeld, Germany). Additionally, one eugenolcontaining temporary luting cement was included into this study: RelyX Temp E (3 M ESPE, Seefeld, Germany). The temporary luting cement materials, their composition, their batch numbers, and their manufacturers are described in Table 1.

Samples of the materials were prepared according to manufacturers' directions under aseptic conditions to prevent the risk of biological contamination during the cytotoxicity testing. Temporary cements were prepared in sterile Teflon rings ( $5 \mathrm{~mm}$ in diameter, $2 \mathrm{~mm}$ high). After 10 minutes of setting tested materials in a humidified atmosphere of $95 \%$ air $/ 5 \% \mathrm{CO}_{2}$ at $37^{\circ} \mathrm{C}$, seven specimens per material were transferred into one insert (Millipore: $0.4 \mu \mathrm{m}$ pore size, $30 \mathrm{~mm}$ diameter) of a six-well plate. The test specimens were covered with a $3 \mathrm{~mL}$ cell culture medium [ $\alpha$-MEM supplemented with $20 \%$ FBS, Geneticin, and penicillin/streptomycin] and incubated for $24 \mathrm{~h}$ in a humidified atmosphere of $95 \%$ air $/ 5 \%$ $\mathrm{CO}_{2}$ at $37^{\circ} \mathrm{C}$. Thus, extracts of the test specimens were prepared at a ratio of $91.6 \mathrm{~mm}^{2}$ sample surface area/mL cell culture medium following the recommendations of ISO [14].

Clonal SV40 large T-antigen-transfected bovine dental pulp-derived cells were routinely cultivated in $\alpha$-MEM supplemented with $20 \%$ FBS, penicillin (150 IU/mL), Geneticin $(0.1 \mathrm{mg} / \mathrm{mL})$, and streptomycin $(150 \mu \mathrm{g} / \mathrm{mL})$ at $37^{\circ} \mathrm{C}$ and $5 \%$ $\mathrm{CO}_{2}$, as previously described [15]. Cells within passages 19 to 23 were used.

The bovine dental pulp-derived cells were seeded at a density of $5 \times 10^{3}$ into each well of a 96-well plate and incubated for 24 hours at $37^{\circ} \mathrm{C}$. Then, the cell cultures were exposed to either $200 \mu \mathrm{L}$ original extracts of the test specimens or a medium as a negative control. Cell viability was than determined by enzyme activity (MTT assay). Cell cultures were washed with phosphate-buffered saline (PBS). Subsequently, $200 \mu \mathrm{L}$ aliquots of freshly prepared MTT solution $(0.5 \mathrm{mg} / \mathrm{mL}$ in growth medium $)$ was added to each well and incubated for $2 \mathrm{~h}$ at $37^{\circ} \mathrm{C}$. The cells were then washed two times with PBS. The blue formazan precipitate was extracted from the mitochondria by using $200 \mu \mathrm{L}$ of dimethyl sulfoxide on a shaker at room temperature for $30 \mathrm{~min}$. The absorption at $540 \mathrm{~nm}\left(\mathrm{OD}_{540}\right)$ was determined spectrophotometrically. Twelve wells were used for each specimen in two independent experiments $(n=24)$. Optical density readings detected in cultures exposed to extracts were normalized to untreated control cultures $(=100 \%)$. The data were normally distributed. Results were statistically analyzed by one-way ANOVA followed by the Tukey-HSD test for post hoc comparisons ( $\alpha=0.05$; SPSS version 13.0; SPSS, Chicago, IL).

2.2. Dentin Barrier Test. The cytotoxicity of the temporary luting cements was also evaluated in a dentin barrier test device using three-dimensional cell cultures of bovine dental pulp-derived cells. Three-dimensional cultures of bovine dental pulp-derived cells were prepared as previously described $[9,16]$.

Polyamide meshes $\left(0.5 \mathrm{~cm}^{2}\right.$; Reichelt Chemietechnik, Heidelberg, Germany) were immersed in $0.1 \mathrm{M}$ of acetic acid for $30 \mathrm{~min}$, washed three times with PBS, and air dried. Next, meshes were coated with fibronectin $(0.03 \mathrm{mg} / \mathrm{mL}$; Sigma, Deisenhofen, Germany) and air dried. Cell culture inserts (Millipore, Eschborn, Germany) were placed into six-well plates with $1.25 \mathrm{~mL}$ of growth medium per well. The meshes were placed on the inserts, and $20 \mu \mathrm{L}$ of cell suspension $(4 \times$ $10^{6}$ cells $/ \mathrm{mL}$ ) was seeded on them. After $48 \mathrm{~h}$ of incubation $\left(37^{\circ} \mathrm{C}, 5 \% \mathrm{CO}_{2}, 100 \%\right.$ humidity), the meshes were transferred to 24-well plates and incubated until they were used for cytotoxicity experiments ( $14 \pm 2$ days). The culture medium (growth medium supplemented with $50 \mathrm{~g} / \mathrm{mL}$ of ascorbic acid) was changed three times a week.

A commercially available cell culture perfusion chamber (Minucells \& Minutissue GmbH, Bad Abbach, Germany) made of polycarbonate with a base of $40 \times 40 \mathrm{~mm}$ and a height of $36 \mathrm{~mm}$ was modified. The three-dimensional cultures were placed on a dentin disc held in place by a special biocompatible stainless-steel holder, resulting in a dentin barrier test situation. The dentin disc $(500 \pm 20 \mu \mathrm{m}$ thick $)$ was cut from a bovine incisor, etched on the pulpal side with $50 \%$ citric acid for $30 \mathrm{~s}$, and sterilized by autoclaving as described [16]. Thus, the cell culture chamber was separated into two compartments by the dentin disc. The cell culture tissues were placed in direct contact with the etched side of the dentin disk and held in place by the stainless-steel holder. All chambers were perfused with $0.3 \mathrm{~mL}$ of assay medium (growth medium with $5.96 \mathrm{~g} / \mathrm{L}$ HEPES buffer, Merck, Germany) per hour for $24 \mathrm{~h}$ at $37^{\circ} \mathrm{C}$. Perfusion was switched off; test materials were introduced into the upper compartment in direct contact with the "cavity" side of the dentin disc. Test materials were applied according to the manufacturers' instructions. 
TABLE 1: Test materials, lot numbers, and compositions.

\begin{tabular}{|c|c|}
\hline Material & Composition \\
\hline $\begin{array}{l}\text { Provicol } \\
\text { Eugenol-free temporary luting cement with calcium } \\
\text { hydroxide } \\
\text { Lot: base: } 770518 \text {; catalyst: } 770520 \\
\text { Voco GmbH, Cuxhaven, Germany }\end{array}$ & $\begin{array}{l}\text { Zinc oxide, magnesium oxide, calcium hydroxide, fatty acids, } \\
\text { vegetable oils, polyglycols, rosin, fumed silica }\end{array}$ \\
\hline $\begin{array}{l}\text { PreVISION CEM } \\
\text { One-component, eugenol-free, silicone-resin-based } \\
\text { temporary cement } \\
\text { Lot: } 255475 \\
\text { Heraeus Kulzer GmbH \& Co. KG, Hanau, Germany }\end{array}$ & Zinc oxide, pyrogenic silica, titanium tetrapropanolate, fillers/binders \\
\hline $\begin{array}{l}\text { RelyX Temp NE } \\
\text { Temporary cement-zinc oxide noneugenol } \\
\text { Lot: base: } 317895 \text {; catalyst: } 318276 \\
\text { 3M ESPE AG, Seefeld, Germany }\end{array}$ & $\begin{array}{l}\text { Catalyst: rosin, reaction products with acrylic acid, nonanoic acid, } \\
\text { silane treated silica } \\
\text { Base: zinc oxide, white mineral oil (petroleum), petrolatum }\end{array}$ \\
\hline $\begin{array}{l}\text { RelyX Temp E } \\
\text { Temporary cement-zinc oxide-eugenol } \\
\text { Lot: base: } 239526 \text {; catalyst: } 239869 \\
\text { 3M ESPE AG, Seefeld, Germany } \\
\end{array}$ & $\begin{array}{l}\text { Modified rosin, hydrogenated rosin eugenol, silane treated silica, oleic } \\
\text { acid, 2,6-di-tert-butyl-p-cresol }\end{array}$ \\
\hline
\end{tabular}

A nontoxic polyvinylsiloxane impression material (President, Coltene) was used as a negative control (100\% cell viability).

Cytotoxicity of test materials was recorded after the pulpal part of the in vitro pulp chamber was perfused with the cell culture medium $(2 \mathrm{~mL} / \mathrm{h})$ for $24 \mathrm{~h}$ of incubation at $37^{\circ} \mathrm{C}$. Five chambers were used for each material in two independent experiments ( $n=10$ ); after 24 h of incubation, the vitality of the cultures was determined using the MTT assay.

Cell viability of the three-dimensional cultures was determined by enzyme activity (MTT assay). The tissues were removed from the pulp chambers, placed into 24 -well plates containing $1 \mathrm{~mL}$ of prewarmed MTT solution $(0.5 \mathrm{mg} / \mathrm{mL}$ in growth medium), and incubated for $2 \mathrm{~h}$ at $37^{\circ} \mathrm{C}$. Then, the cells were washed two times with PBS. The blue formazan precipitate was extracted from the mitochondria using $0.5 \mathrm{~mL}$ of dimethyl sulfoxide on a shaker at room temperature for $30 \mathrm{~min}$. Next, $200 \mu \mathrm{L}$ of this solution was transferred to a 96-well plate, and the absorption at $540 \mathrm{~nm}\left(\mathrm{OD}_{540}\right)$ was determined spectrophotometrically. The median $\mathrm{OD}_{540}$ of control tissue (cell cultures exposed to the polyvinylsiloxane impression material) was set to represent $100 \%$ viability. Results of the cytotoxicity experiments were expressed as a percentage of matching control tissue, and differences between median values were statistically analyzed using the Kruskal-Wallis one-way analysis of variance (ANOVA) and the Mann-Whitney $U$ test ( $\alpha=0.05$; SPSS version 13.0; SPSS, Chicago, IL).

\section{Results}

The results of the cytotoxicity studies with two-dimensional cultures of bovine dental pulp-derived cells are summarized in Figure 1. The average percentage of cell viability after exposure to the extracts of RelyX Temp E, Provicol, PreVISION CEM, and RelyX Temp NE was $89.1 \%, 84.9 \%$, 92.3\%, and $66.8 \%$, respectively. RelyX Temp NE significantly decreased the cells' viability compared to the control group $(P=$ 0.000 ), and the difference in survival rates between RelyX Temp NE and all other tested temporary luting cements was statistically significant $(P<0.01)$. Provicol was the other temporary luting cement showing some cytotoxic effects on bovine dental pulp-derived cells. Provicol decreased the cells' viability compared to the control group $(P=0.04)$; however, the difference in survival rates among Provicol, RelyX Temp E, and PreVISION CEM was not statistically significant $(P>$ 0.05). RelyX Temp E and PreVISION CEM were not cytotoxic on bovine dental pulp-derived cells $(P>0.05)$.

The cytotoxicity of the temporary luting cements was also determined in three-dimensional cell cultures introduced in a dentin barrier test device (Figure 2). None of the temporary luting cements significantly reduced cell survival when compared with the negative control in dentin barrier test $(P>0.05)$. Exposure of the cell cultures to Provicol, PreVISION CEM, and RelyX Temp NE led to 91.9\%, 93.5\%, and $90.6 \%$ cell survival. On the contrary, slightly increased cell vitality was observed with RelyX Temp E (101.5\%).

\section{Discussion}

In the present study, the cytotoxic reaction of transfected bovine pulp-derived cells after exposure to temporary luting cements was evaluated by two in vitro test methods. The hypothesis of this study can be partly accepted because two of the tested temporary luting cements (Rely X Temp NE and Provicol) were cytototoxic to the two-dimensional monolayer cultures of bovine pulp-derived cells. On the other hand, none of the temporary luting cements were cytotoxic to the three-dimensional cultures of bovine pulp-derived cells (dentin barrier test).

According to national and international regulations, dental materials have to be evaluated for biocompatibility 


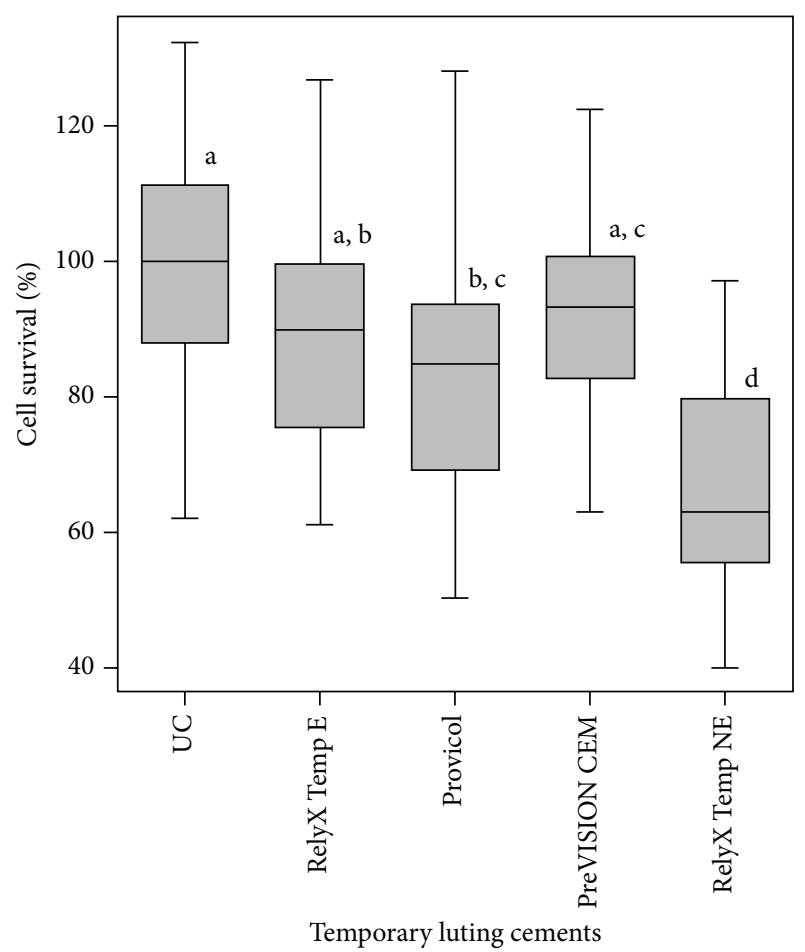

FIgUre 1: Cytotoxicity of temporary luting cements on twodimensional cultures of transfected bovine pulp-derived cells. The cell cultures were exposed for $24 \mathrm{~h}$, and cellular survival in treated and untreated cell cultures was determined $(n=24)$. The different small letters over each box indicate significant differences in cytotoxicity. UC, untreated controls.

before being applied to patients. For this purpose, animal experiments or cell culture tests are available. Animal experiments to test the cytotoxicity of dental materials are time consuming, expensive, and subject to extensive public discussions. In vitro cytotoxicity test has the advantage of easy control of experimental factors that are often problematic when performing experiments in vivo. In vitro methods are reproducible, cost effective, relevant, and suitable for the evaluation of basic biological properties of dental materials $[10,17]$. Different in vitro test methods and cell lines have been used to determine dental materials' cytotoxicity. Primary pulp cells are closely related to their original tissue and have a nearly unchanged metabolic state relative to their original tissue. Thus, an in vivo situation may be better simulated by primary pulp cell cultures [18]. However, the isolation of primary cells from target tissues is labor intensive and time consuming, and the resulting cell numbers are often very low compared to the almost unlimited number of cells obtained from continuous cell lines. Additionally, primary pulp cells in cultures have a limited capacity to divide and soon reach a nonproliferative state, probably due to chromosomal alterations. This cellular senescence dramatically limits the availability of cells derived from pulp to investigate responses to material exposure. To overcome these shortcomings, Thonemann and Schmalz introduced an immortalized bovine dental pulp-derived cell line. This cell



FIGURE 2: Cytotoxicity of temporary luting cements on threedimensional cultures of transfected bovine pulp-derived cells (dentin barrier test). Data are expressed as percentage of the negative control (President) cultures $(n=10)$. The same small letters over each box indicate no significant differences in cytotoxicity.

line, which is also used in the present study as the target cell line, was shown to have similar biochemical characteristics as primary dental pulp cells $[15,16,19]$.

Adequate contact between cells and test material is crucial for cell cytotoxicity testing. To simulate the in vivo situation for temporary luting cements, in vitro pulp chambers have been used in the present study, introducing dentin as a barrier between test materials and target cells. Transformed bovine dental pulp-derived cells were grown as three-dimensional cultures and included in a dentin barrier test device to mimic the interactions between the target cells and test materials that occur in vivo $[9,16,20-22]$. An additional advantage of this artificial pulp chamber was thought to be the possibility of perfusing the pulpal part with a nutrition medium, thus simulating in vivo pulpal blood flow [9].

In the present study, dentin proved to be protective for temporary luting cements. Temporary luting cements were not cytotoxic on bovine pulp-derived cells, although only $0.5 \mathrm{~mm}$ thick dentin was used as a barrier. In accordance with our data, dentin has been shown to reduce the toxicity of certain dental materials [23]. Permeability measurements have shown dentin to be a partial perfusion/diffusion barrier [24]. Dentin acts as a diffusion and adsorption barrier, thus reducing the concentration of eluted substances that reach the pulp and possibly cause tissue reactions $[25,26]$; it is also considered a solid buffer, neutralizing protons derived from acids 
[23]. Dentin has also been shown to act as a barrier, decreasing the elicited cytotoxicity with increasing thickness [27].

Zinc oxide eugenol is one of the major components of a number of temporary cements because of its bacteriostatic effect, low cost, ease of removal, and good sealing ability [28]. This material elicits a strong reaction in vitro [17], but it does not damage the pulp in the same way when applied to the dental cavity with an intact dentin layer in vivo [16]. It has been postulated that the dentin layer is responsible for the different results obtained in vivo and in vitro. Dentin has the ability to absorb eugenol and zinc [27]. The results of this study suggest that eugenol-containing temporary cement (RelyX Temp E) is not cytotoxic to pulp-derived cells, even if a dentin barrier does not exist.

However, the existence of a dentin barrier over the pulp cells seems to be more critical for eugenol-free temporary cements. Although Rely X Temp NE and Provicol were found to be nontoxic in the dentin barrier test, they significantly decreased the survival rate of pulp-derived cells in twodimensional cultures. Provicol is a calcium-hydroxide-based temporary luting cement. Recently, a number of studies have focused on the biocompatibility of calcium-hydroxidebased endodontic sealers and pulp-capping materials. Van Landuyt et al. reported that the calcium-hydroxide-based root canal sealer Calcicur was not genotoxic to human gingival fibroblasts [28]. Hirschman et al. evaluated three of the current direct pulp-capping agents and reported that among them only Dycal was shown to have a statistically significant cytotoxic effect on adult human dermal fibroblasts [29]. Camargo et al. analyzed cellular reactions to the pulp capping materials. It appeared that only the calcium hydroxide preparation Hydro C was cytotoxic on human pulp derived cells [30].

RelyX Temp NE and Provicol both include zinc oxide and rosin. Combinations of rosin and zinc are used in dentistry as components of periodontal dressings and cements and as root canal sealers. Sunzel et al. [31] showed that rosins and pure resin acids had a strong dose-related cytotoxicity that was inhibited by increased zinc concentrations. These materials showed cytotoxic effects in this study as well. Another ingredient of RelyX Temp NE is acrylic acid, and Kurata et al. [32] showed that fibroblast growth decreased upon exposure to acrylic acid as acid increased. RelyX Temp NE was found to be the most toxic temporary luting cement on two-dimensional cultures in the present study. On the other hand, PreVISION CEM also contains zinc oxide, and this material was not cytotoxic to bovine pulp-derived cells in both tests.

\section{Conclusion}

The findings presented here imply that biologically active substances may be released from temporary luting cements and eventually damage pulp-derived cells. However, biologically active substances released from temporary luting cements may not influence the dentine-pulp complex if the residual dentine layer is at least $0.5 \mathrm{~mm}$ thick.

\section{Conflict of Interests}

The authors declare that there is no conflict of interests.

\section{References}

[1] S. Chandra, S. Chandra, and G. Chandra, Textbook of Operative Dentistry, Jaypee Brothers Medical, New Delhi, India, 1st edition, 2007.

[2] J. C. V. Ribeiro, P. G. Coelho, M. N. Janal, N. R. F. A. Silva, A. J. Monteiro, and C. A. O. Fernandes, "The influence of temporary cements on dental adhesive systems for luting cementation," Journal of Dentistry, vol. 39, no. 3, pp. 255-262, 2011.

[3] S. J. Paul and P. Schärer, "Effect of provisional cements on the bond strength of various adhesive bonding systems on dentine," Journal of Oral Rehabilitation, vol. 24, no. 1, pp. 8-14, 1997.

[4] P. Baldissara, G. Comin, F. Martone, and R. Scotti, "Comparative study of the marginal microleakage of six cements in fixed provisional crowns," The Journal of prosthetic dentistry, vol. 80, no. 4, pp. 417-422, 1998.

[5] S. F. Rosenstiel, M. F. Land, and J. Fujimoto, Contemporary Fixed Prosthodontics, Mosby Elsevier, St. Louis, Mo, USA, 4th edition, 2006.

[6] P. S. Olin, J. D. Rudney, and E. M. Hill, "Retentive strength of six temporary dental cements," Quintessence international, vol. 21, no. 3, pp. 197-200, 1990.

[7] P. P. C. Souza, A. M. F. Aranha, J. Hebling, E. M. A. Giro, and C. A. D. S. Costa, "In vitro cytotoxicity and in vivo biocompatibility of contemporary resin-modified glass-ionomer cements," Dental Materials, vol. 22, no. 9, pp. 838-844, 2006.

[8] A. Bakopoulou, D. Mourelatos, A. S. Tsiftsoglou, N. P. Giassin, E. Mioglou, and P. Garefis, "Genotoxic and cytotoxic effects of different types of dental cement on normal cultured human lymphocytes," Mutation Research, vol. 672, no. 2, pp. 103-112, 2009.

[9] H. E. Ülker and A. Şengün, "Cytotoxicity evaluation of self adhesive composite resin cements by dentin barrier test on $3 \mathrm{~d}$ pulp cells," European Journal of Dentistry, vol. 3, no. 2, pp. 120126, 2009.

[10] N. Kong, T. Jiang, Z. Zhou, and J. Fu, "Cytotoxicity of polymerized resin cements on human dental pulp cells in vitro," Dental Materials, vol. 25, no. 11, pp. 1371-1375, 2009.

[11] M. Schmid-Schwap, A. Franz, F. König et al., "Cytotoxicity of four categories of dental cements," Dental Materials, vol. 25, no. 3, pp. 360-368, 2009.

[12] C. A. S. Costa, J. Hebling, and R. C. Randall, "Human pulp response to resin cements used to bond inlay restorations," Dental Materials, vol. 22, no. 10, pp. 954-962, 2006.

[13] B. Bagis, P. Atilla, N. Cakar, and U. Hasanreisoglu, "An immunohistochemical evaluation of cell adhesion molecules in human dental pulp after tooth preparation and application of temporary luting cements," Oral Surgery, Oral Medicine, Oral Pathology, Oral Radiology and Endodontology, vol. 107, no. 1, pp. 137-144, 2009.

[14] International Organization for Standardization, "Biological evaluation of medical devices-part 12: sample preparation and reference materials," ISO, 10993-12:2007, Case postal 56, CH1211 Geneva 20, Switzerland, 2007.

[15] B. Thonemann and G. Schmalz, "Immortalization of bovine dental papilla cells with simian virus 40 large t antigen," Archives of Oral Biology, vol. 45, no. 10, pp. 857-869, 2000. 
[16] G. Schmalz, U. Schuster, B. Thonemann, M. Barth, and S. Esterbauer, "Dentin barrier test with transfected bovine pulpderived cells," Journal of Endodontics, vol. 27, no. 2, pp. 96-102, 2001.

[17] G. Schmalz, "Use of cell cultures for toxicity testing of dental materials-advantages and limitations," Journal of Dentistry, vol. 22, supplement 2, pp. S6-S11, 1994.

[18] W. Geurtsen, "Biocompatibility of resin-modified filling materials," Critical Reviews in Oral Biology and Medicine, vol. 11, no. 3, pp. 333-355, 2000.

[19] B. Thonemann and G. Schmalz, "Bovine dental papilla-derived cells immortalized with H PV 18 E6/E7," European Journal of Oral Sciences, vol. 108, no. 5, pp. 432-441, 2000.

[20] G. Schmalz, "Cytotoxicity testing with three-dimensional cultures of transfected pulp-derived cells," Journal of Endodontics, vol. 27, no. 4, pp. 259-265, 2001.

[21] G. Schmalz, U. Schuster, A. Koch, and H. Schweikl, "Cytotoxicity of low $\mathrm{pH}$ dentin-bonding agents in a dentin barrier test in vitro," Journal of Endodontics, vol. 28, no. 3, pp. 188-192, 2002.

[22] M. Demirci, K.-A. Hiller, C. Bosl, K. Galler, G. Schmalz, and H. Schweikl, "The induction of oxidative stress, cytotoxicity, and genotoxicity by dental adhesives," Dental Materials, vol. 24, no. 3, pp. 362-371, 2008.

[23] W. R. Hume, "Influence of dentine on the pulpward release of eugenol or acids from restorative materials," Journal of Oral Rehabilitation, vol. 21, no. 4, pp. 469-473, 1994.

[24] C. T. Hanks, J. C. Wataha, R. R. Parsell, S. E. Strawn, and J. C. Fat, "Permeability of biological and synthetic molecules through dentine," Journal of Oral Rehabilitation, vol. 21, no. 4, pp. 475487, 1994.

[25] G. Schmalz, M. Hoffmann, K. Weis, and H. Schweikl, "Influence of albumin and collagen on the cell mortality evoked by zinc oxide-eugenol in vitro," Journal of Endodontics, vol. 26, no. 5, pp. 284-287, 2000.

[26] S. D. Meryon and K. J. Jakeman, "Uptake of zinc and fluoride by several dentin components," Journal of Biomedical Materials Research, vol. 21, no. 1, pp. 127-135, 1987.

[27] K. Galler, K.-A. Hiller, T. Ettl, and G. Schmalz, "Selective influence of dentin thickness upon cytotoxicity of dentin contacting materials," Journal of Endodontics, vol. 31, no. 5, pp. 396-399, 2005.

[28] K. L. Van Landuyt, B. Geebelen, M. Shehata et al., "No evidence for DNA double-strand breaks caused by endodontic sealers," Journal of Endodontics, vol. 38, no. 5, pp. 636-641, 2012.

[29] W. R. Hirschman, M. A. Wheater, J. S. Bringas, and M. M. Hoen, "Cytotoxicity comparison of three current direct pulpcapping agents with a new bioceramic root repair putty," Journal of Endodontics, vol. 38, no. 3, pp. 385-388, 2012.

[30] S. E. A. Camargo, C. H. R. Camargo, K.-A. Hiller, S. M. Rode, H. Schweikl, and G. Schmalz, "Cytotoxicity and genotoxicity of pulp capping materials in two cell lines," International Endodontic Journal, vol. 42, no. 3, pp. 227-237, 2009.

[31] B. Sunzel, T. A. Söderberg, A. Johansson, G. Hallmans, and R. Gref, "The protective effect of zinc on rosin and resin acid toxicity in human polymorphonuclear leukocytes and human gingival fibroblasts in vitro," Journal of Biomedical Materials Research, vol. 37, no. 1, pp. 20-28, 1997.

[32] S. Kurata, K. Morishita, T. Kawase, and K. Umemoto, "Cytotoxic effects of acrylic acid, methacrylic acid, their corresponding saturated carboxylic acids, HEMA, and hydroquinone on fibroblasts derived from human pulp," Dental Materials Journal, vol. 31, no. 2, pp. 219-225, 2012. 

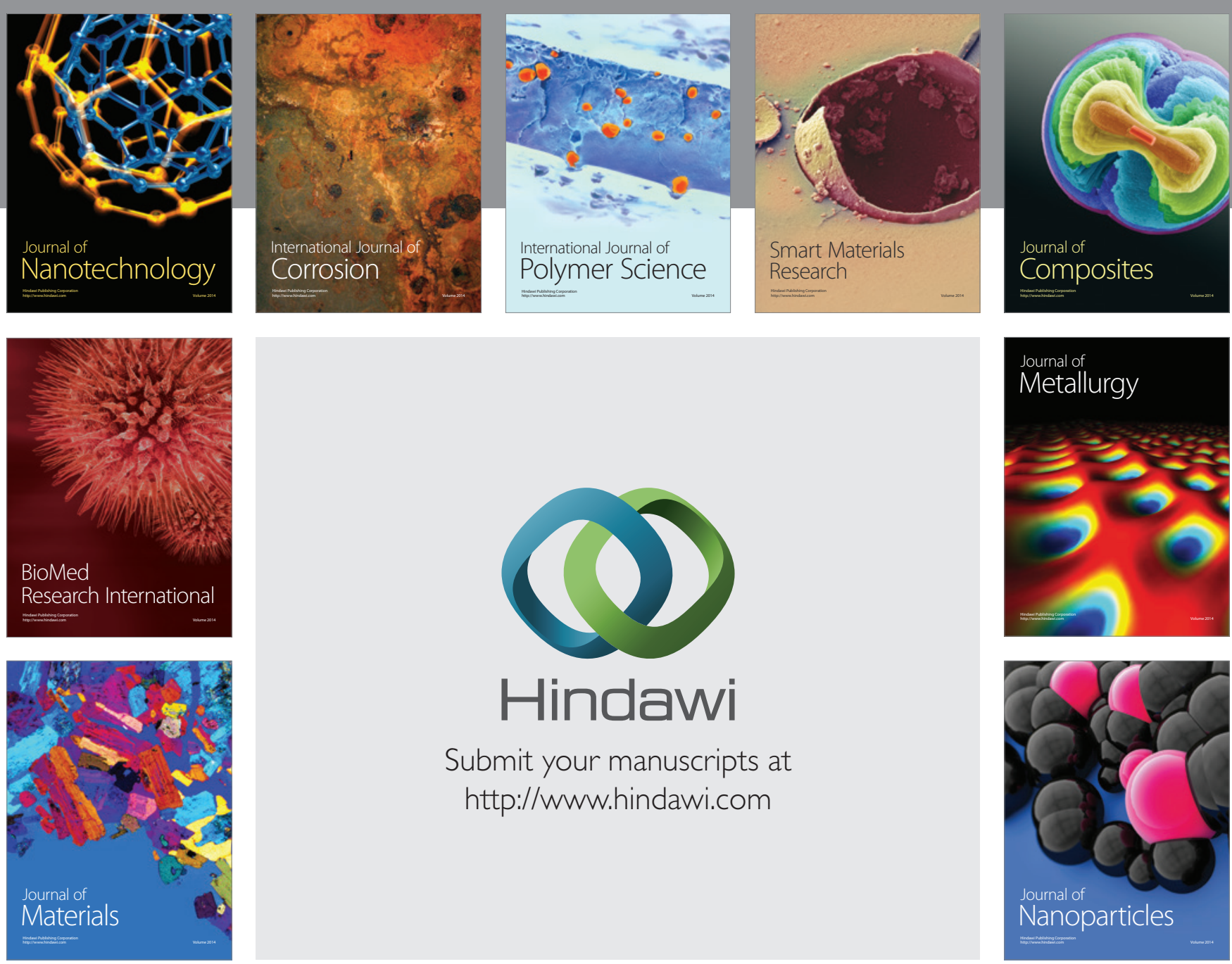

Submit your manuscripts at http://www.hindawi.com
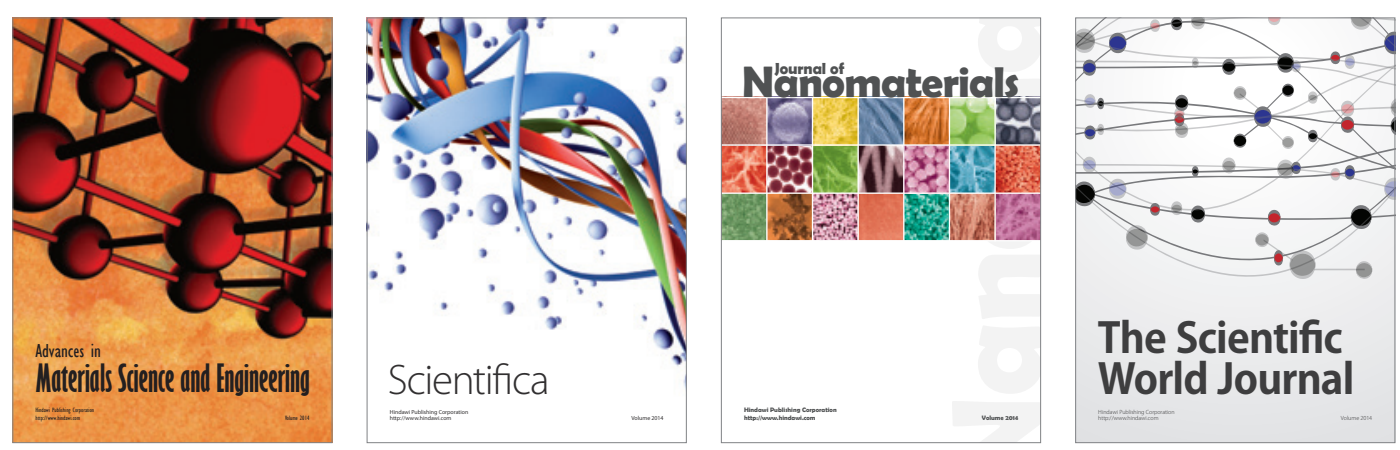

\section{The Scientific World Journal}
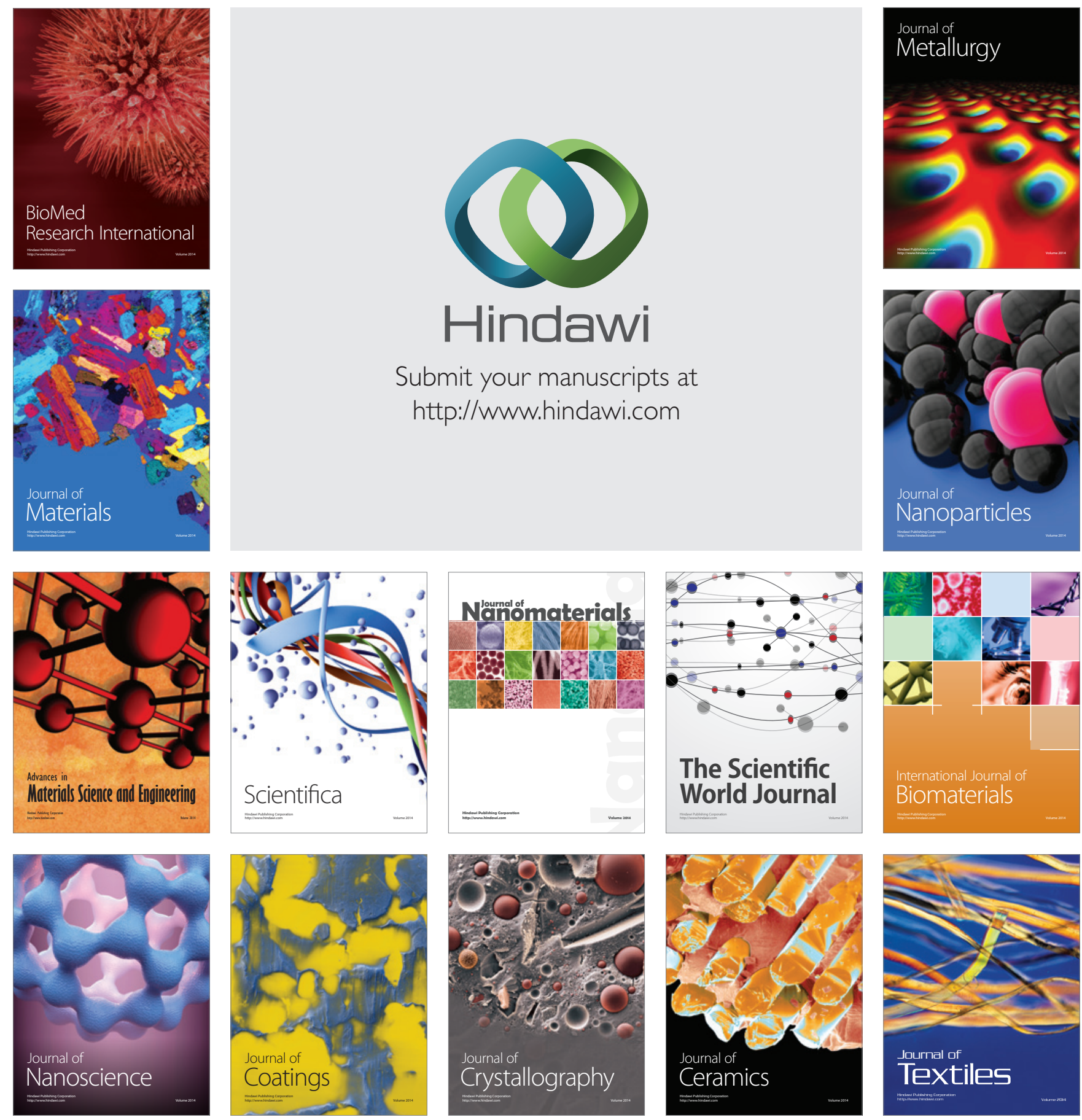